\title{
The Role Of Foreign Ownership In Moderating The Effect Of Company Size On Intellectual Capital Disclosure
}

\author{
Ming Chen \\ Fakultas Bisnis dan Akuntansi \\ Universitas Katolik Musi Charitas Palembang \\ ming_chen@ukmc.ac.id
}

\begin{abstract}
The purpose of the empirical study is to examine whether foreign ownership in moderating the relationship between company size and disclosure of intellectual capital. In this study, the variables of foreign ownership are measured by the amount of foreign ownership divided by the total number of shareholders in the company. The size of the company is proxied by Market Capitalization. Moreover, the disclosure of intellectual capital is measured by the ICD (Intellectual Capital Disclosure) Index which amounts to 25 items. The sample of this research is manufacturing companies listed on the Indonesia Stock Exchange from 2014 to 2017. This study uses the MRA model and uses SPSS as a testing tool. The result of this study is the foreign ownership is able to moderate the relationship between company size and disclosure of intellectual capital.
\end{abstract}

Keywords: Foreign Ownership, Company Size, Disclosure of Intellectual Capital.

\section{INTRODUCTION}

The condition of the world economy in the era of globalization is currently experiencing very rapid development, this makes all countries in the world innovate in order to compete with other countries. Indonesia is a country that has also experienced rapid development because Indonesia is included in the Southeast Asian region (ASEAN) which has begun to integrate to improve competitiveness in the current economic arena. The meeting of leaders of ASEAN countries agreed to form a single market in the ASEAN region, known as the ASEAN Economic Community (AEC). The enactment of the ASEAN Economic Community as a challenge and at the same time a great opportunity that must be able to face by society and companies in Indonesia, especially in facing global competition and improving the Indonesian economy. This enforcement in every company in Indonesia is able to maintain its existence or even leading in competition amid the AEC the flow of the free market.

Human resources in Indonesia is able to compete with other countries. With the existence of a free market, the AEC does not only make companies have to be able to compete but also causes people to be able to improve their competence. In addition, business conditions that are changing rapidly will surely provide a lot of impact on financial reporting of an organization especially those related to the presentation and valuation of intangible assets (Sri, 2018).

Statement from (Berzkalne and Zelgalve, 2014) that organizational management must be able to compete and increase the value of their organization. An organization can 
maintain a company from an unstable economic condition must implement an organizational business strategy that used to implement labor strategies (Labor Based Business) into a knowledge-based business strategy (knowledge-based business). In addition, companies need basic capital to achieve a company goal consisting of physical capital, financial capital and intellectual capital.

In PSAK No. 19 (revised 2009) stated that regulates intangible assets which do not regulate Intellectual Capital reporting, causing companies in Indonesia to report less on intellectual capital. According to (Artinah, 2013) disclosure of intellectual capital is a strategy carried out to report the nature of non-measurable (intangible) values that exist in the organization/company.

An organization is assisted by intellectual capital in terms of the formulation of business strategies, implementing strategies, decision-makers in strategy, planning diversification and expansion strategies of the organization which is the basis of the organization's steps to communicate strategies to the company's external parties. An organization must be able to utilize intangible assets to create value without removing analysis in financial statements (Benedetta et al., 2017).

The measurement of intellectual capital cannot be mathematics measured because intellectual capital is included in invisible (intangible) assets. But intellectual capital needs to be disclosed in the company's annual report because this information is used by report users to get a lot of information in decision making. This condition is also one way to increase the relevance of financial reports issued by the company in the form of annual reports. Broad relevancy in companies reveals that intellectual capital can be influenced by various company characteristics, including company size. Company size is a report by user scale to measure the size of a company. Large companies have a tendency to provide broader information than small scale companies. Therefore large-scale companies tend to be accounted for by information users compared to small-scale companies. Hence, largescale companies have a tendency to reveal more information about intellectual capital that is expected to reduce the information gap and be able to fulfill the wishes of external parties. In addition, in the larger the scale of the company, the external party has the perception that the company has a good development and has a positive response from external parties because the risks and challenges faced by the company are also higher which causes large scale companies to get a lot of attention from the investors. Moreover, a reference in the company is to report information as widely as possible to external parties (Soraya, 2015).

(Henni, 2014) discussed intellectual capital with the theme of research on what things can affect the disclosure of intellectual capital. The influence in this study is the size of the company, the age of the company while the one that does not have an effect is leverage, profitability, independent commissioner and concentration of ownership. The research differs from previous research because the researchers added moderating variables namely foreign ownership. The tendency of large-scale companies to have foreign ownership in their companies. With the presence of foreign ownership, large-scale companies are expected to be able to disclose their intellectual capital reporting more deeply to attract foreign attention. Indonesia has a high foreign investment. Based on data obtained from the Capital Investment Coordinating Board (CICB), the realization of investment in the first quarter of 2016 was Rp. 146.5 Trillion or up $17.6 \%$ from the 
previous period. It consists of Foreign Investment of Rp. 96.1 Trillion or up $17.1 \%$ from the previous period.

\section{THEORETICAL REVIEW}

Signaling Theory. A signal is a condition where the company provides information that is important and influences decisions from users of information so that information users can make the right decisions from the information provided by the organization. According to (Brigham and Houston, 2011) signal is an action carried out by a company organization that has a plan to provide an overview to the user of the report regarding the condition of the company reported by the management in the organization.

The company seeks to provide information to external parties. The benefits of intellectual capital reports are that companies can provide more information to users of the report so that users can understand more deeply the condition of the company and know the strategies developed by the company in the use of intellectual capital. When the signal is given positively, the company will get a positive response from the user and the assessment of the company also increases. All information created in the company becomes very crucial for stakeholders because the information presented can be a picture of the company that portrays the company in the past, present and future. And information can provide added value to the material for investors to analyze and make investment decisions.

Stakeholder Theory. Statement from (Purnomosidhi, 2016) an organization must be able to carry out activities that are in accordance with the expectations of stakeholders and must be able to provide information about activities to stakeholders. Stakeholder as a funder for the company has the right to all the conditions of the company and the activities of the company will be able to contribute to decision making both information that they will use or information that is not useful in their decisions.

Stakeholder theory states companies are not organizations that establish for themselves but how organizations can provide benefits to others. The company's reputation is strongly influenced by stakeholders; the company will continue to try to manage good relationships with stakeholders by providing the information needed by them. The responsibility of the company to stakeholders is not only on economic or financial performance but conditions beyond that so companies need to disclose beyond the disclosures and enter into voluntary disclosures, such as disclosure of intellectual capital. Voluntary disclosure by companies can be in the form of how much disclosure of intellectual capital will be used as a calculation by the company to increase the value of the company, especially for large-sized companies.

Agency theory. The existence of agency theory because of a problem that occurs between the company manager and corporate funders and this occurs in the agency relationship. The existence of different interests between the two parties in the organization will result in prolonged conflict in this organization. This conflict can occur due to different desires, e.g. the manager as management are willing to have a large salary/ bonus from the company while the funder would like the manager to manage the company well, hence it 
can generate a lot of profits for him. (Jensen and Meckling, 1976) explained agency theory is a condition that mentions about the relationship between two parties in a company, the manager (agent) and the funder (principal). Agency theory stated that agency relations exist when one of the parties (principal) provides management authority to the manager (agent) to carry out the task for their interests which involves giving authority to several decision-making authorities to the manager. This condition causes the agent to carry out the tasks given by the funder, which later results will provide welfare to the funder. This condition causes distrust of funders to managers because of differences in interests of both parties so that at this time the conflict occurred between the two parties concerned.

This conflict is getting bigger in companies that have large business complexity so that good and independent supervision is needed to oversee the actions of managers in carrying out the delegation of tasks from the funders. One of the things that can reduce this conflict is supervision from the outside if the company is owned by foreigners, thus the information will be presented by the company which is relevant.

Disclosure of Intellectual Capital. Disclosure of intellectual capital is an important thing to disclose in an organization, indeed intellectual capital is an intangible asset that must be owned by an organization which later will have a purpose in determining the value of an organization by the community. Intellectual capital relates to assets in a company that must have a knowledge base or the result of a knowledge transformation process in the form of intellectual assets (Eka and Yulida, 2018)

Based on (Marisanti, 2012) stated that there are several methods in intellectual capital that are lateral in nature in the form of companies in innovating, creative and developing conventional variables and applying other technical values including in terms of experiences where past experience is a learning process for companies.

Intellectual capital is developed into 3 characteristics including:

Human Capital. Human capital is a company that has the collective ability to provide solutions within the company based on the skills of human resources in the company. Human capital as the lifeblood in intellectual capital because it is a creative source in the company and is a difficult variable to measure because this condition exists in human resources in the company which can be seen from the creativity and innovation of the workforce.

Organizational Capital or Structural Capital. Organizational capital encompasses organizational excellence to regulate the company's business processes and regulate the workforce in order to provide optimal performance in the overall business.

Relational Capital or Customer Capital. Relational capital can be referred to as customer capital which is a variable of intellectual capital that can be seen in real terms in the form of good conditions between companies and partners such as quality suppliers, loyal customers, good corporate services and company relations with other parties related to the government and society.

Board Diversity. The concept of board diversity is associated with the component of Good Corporate Governance, among others, the size of the board, the diversity of 
characteristics, character, and abilities possessed by each individual who is a member of a company's decision-making board. It can be interpreted that this diversity is an illustration of age, gender, race, culture, religion, background, professionalism, knowledge, expertise, one's experience. The form of diversity experienced by Indonesia itself is the citizenship of the board of directors. According to (Choi et al., 2012) diversity occur because of the company's desire to place foreigners in protecting the interests of board members. The most important thing is the perception of companies that build for the company. It is expected that the emergence of a diversity of citizenship will give a signal if the company can prepare to change corporate governance towards a better way to increase the value of the company.

Foreign Ownership. The share ownership structure is a picture of the transfer of ownership and distribution of power that has the influence of shareholders on the company's business operations. Statement in Law No. 25 of 2007 in article 1 point 6 that foreign ownership companies are individuals of foreign citizens, foreign business entities, and foreign governments that make investments in the territory of the Republic of Indonesia.

With the collaboration of domestic companies with foreign companies, they expect the disclosures given to the public at large. It can be said that multinational companies have a good perception in providing extensive information to other stakeholders in terms of the quality of information disclosure. This is one of the positive things that can be taken by domestic companies so that disclosures disclosed by companies can be more and better.

Company Size. The size of the company is divided into 3 categories: large-scale companies, medium-scale companies, and small-scale companies. The larger the size of the company, the more the company will disclose company information widely compared to small-scale companies (Sri, 2018). The size of the company is reflected in the scale of the company's size as measured by the value of the company's assets. The greater the wealth, the more developed a company. Large companies interpret that the company has large funds for the company's operations. Large funds allow companies to invest their funds in intangible assets, namely the disclosure of intellectual capital. The availability of large funds will make the management of intellectual capital more optimal and provide better intellectual capital performance.

Foreign Ownership, Company Size, and Intellectual Capital Disclosure. Company size is the condition in the company shows the size of a company. Companies that have large scale sizes tend to be more concerned by external parties, so this company will provide more information to external parties. Large-scale companies are considered more able to disclose as much information as possible compared to companies on a small scale. Large-scale companies usually have many shareholders and means that this type of company must be able to disclose information as widely as possible to shareholders because of requests from shareholders and analysis in the capital market. The variables used can explain how broad the company's disclosures in the company's annual report are the size of the company. So that large-scale companies will be more revealing voluntary reports of intellectual capital. 
Share ownership structure is a reflection of the distribution of power and influence of shareholders on the company's operations. Researcher (Mishari, 2018) stated that the mechanism of corporate governance greatly impacts the quality of disclosure of intellectual capital disclosed in the company's annual report. The company has many board members, the proportion of external parties is high and the ownership of shares owned by external is high, it will increase the disclosure of intellectual capital. This identifies the larger the company the more foreign ownership in the company. The amount of foreign ownership in the company causes the company to provide more information to shareholders so that the disclosure of intellectual capital is higher.

H1 = Foreign ownership is able to moderate the relationship between company size and disclosure of intellectual capital

Previous researches. Some previous studies that examined foreign ownership, company size and disclosure of intellectual capital:

1. According to (Devanela and Sekar, 2016) with the title of things - things that affect the disclosure of intellectual capital. The result of this study stated that the age of the company and the level of growth affect the disclosure of intellectual capital while ownership concentration does not affect intellectual capital disclosure. The control variable in this study is the size of the company, the size of the company has a positive effect on the practice of disclosure of capital intellectuals.

2. According to (Heni and Wahidahwati, 2014) with the title of things - things that affect intellectual disclosure. The research stated that which affected intellectual capital is the size of the company and the probability to influence positively and the age of the company negatively affects and things that do not affect our leverage, independent commissioners and concentration of ownership.

3. According to (Indra and Tarmizi, 2014) with the title Analysis of the Effect of Company Size on Intellectual Capital Performance with Ownership Structure as a Moderating Variable. The result of this study indicated that company size does not affect the disclosure of intellectual capital. Family ownership has a positive and significant effect on the relationship between firm size and the performance of intellectual capital and institutional ownership has a positive and significant influence on the relationship between firm size and intellectual capital performance.

4. According to (Pratignya and Muhammad, 2015) with the title Factors Affecting the Area of Disclosure of Intellectual Capital in Banking Companies on the Stock Exchange in 2011 - 2013. The result showed managerial ownership, institutional ownership and the level of intellectual capital affected with negative direction on broad disclosure intellectual capital. Profitability and leverage have a positive effect on the broad disclosure of intellectual capital. And foreign ownership and government ownership do not affect the broad disclosure of intellectual capital.

5. According to (Fatwa and Deni, 2014) with the title Analysis of the Effect of Corporate Governance, Managerial Ownership and Institutional Ownership on Intellectual Capital Disclosure. The result of the study indicated that corporate governance has an effect on intellectual capital, managerial and institutional ownership does not affect intellectual capital. Company size control variables and ROA have a significant positive effect on 
intellectual capital and leverage control variables have no significant positive effect on intellectual capital.

6. According to (Choirun, 2017) with the title Effect of Profitability, Leverage, Ownership Retention and Company Size against Intellectual Capital Disclosure on Companies That Perform Initial Public Offering. The result of the study stated that the leverage variable, ownership retention and company size did not affect and profitability influenced the intellectual capital disclosure variable.

\section{METHODOLOGY}

Types and Data Sources. The data type of this research is secondary data. Secondary data is a type of data obtained and extracted through the management of second parties in the form of both qualitative and quantitative data. Secondary data in this study from data which is taken based on the company's annual report for the period 2014 - 2017. The research data is taken from the company's annual report listed on the Indonesia Stock Exchange, Indonesian Capital Market Directory and Investment Gallery Unika Musi Charitas Palembang.

Population and Samples. The population is defined as the group of subjects who want to be subjected to the generalization of the result of the study. The population is used in this study is all companies listed on the Indonesia Stock Exchange. The sample is part of the population that is represented and will be examined or part of the number of characteristics possessed by the population represented (Wijoyo, 2011). The sampling technique is divided into 2 groups, sampling techniques probability models and nonprobability models. This study applies a sampling technique with a non-probability model. This is due to taking using a non-probability model if the size of the opportunity for members of the population as samples is unknown. The sampling technique in the chosen non-probability model is Purposive Sampling. Purposive sampling is sampling taken based on a balance that is in accordance with the purpose of the study. Therefore the criteria in this study are:

1. Manufacturing companies listed on the Stock Exchange from 2014 - 2017

2. Companies that have foreign ownership in the company

Method of collecting data. The method of data collection is to use a literature study where the authors carry out data collection with books related to the research to be discussed.

Variables and Variable Measurements. The variable in this study consisted of the dependent variable namely Intellectual Capital. Disclosure of intellectual capital contains components of intangible assets which cause difficulties in carrying out management, measurement and reporting disclosed by the company. Thus, disclosure of intellectual capital is measured using:

$$
\text { ICD index }=\left(\sum \mathrm{di} / \mathrm{M}\right) * 100 \%
$$


Independent variable in research is the size of the company used to classify largescale companies. While the moderating variable in this study foreign ownership is measured by dividing the number of shares held by foreign companies with the total number of shares outstanding. Foreign-owned shares will be obtained by the percentage of shares held by foreign investors in the form of ownership by foreign ownership and including organizations, social foundations, banks, individuals and foreign governments.

Analysis of Moderate Analysis Regresion (MRA)

The regression equation in this study:

$\mathrm{Y}=\mathrm{a}+\mathrm{bX} 1+\mathrm{bX} 2+\mathrm{bX} 1 * \mathrm{X} 2+\mathrm{e}$

Note:

$\mathrm{Y}=$ Company Performance

$\mathrm{X} 1=$ Company size

$\mathrm{X} 2=$ Foreign Ownership

$\mathrm{e}=$ Error

Normality test. Normality test aims to prove the population in research whether population data used is normally distributed or not. Data that has an ordinal scale, interval and usual ratio are measured by normality testing. Data analysis with parametric methods must be free from abnormal data, meaning that the data studied must be in normal conditions. The Kolmogorov Smirnov One-Sample Test used by this study to see normal data or not by looking at a significance level greater than 0.05 or $5 \%$.

Heteroscedasticity Test. For the purpose of the regression model in understanding whether the model has a variance inequality from the residuals between observations of researchers who use Heteroscedasticity tests. If the result of the observations is the same then it is called Homoscedasticity, whereas if it is different it is called Heteroscedasticity. The same model or homoscedasticity can be said that the regression model is in good condition. This is seen from the Plot Graph which occurs between the predictive value of the dependent variable (independent), namely ZPRED and the residual, SRESID. Detection of Heteroscedasticity can be seen using a graph and whether it forms a specific pattern on a scatter-lite graph formed between SRESID and ZPRED. If the result in the graph forms a certain and regular pattern in the formation of a pattern such as a wavy pattern, widening and then narrowing, it can be stated that the regression model under study under conditions is not good or Heteroscedasticity occurs. But it can be said that capital is good and there is no Heteroscedasticity if in a graph there is no particular pattern and the point spreads above and below the zero on the Y-axis (Ghozali, 2012).

T-test. The test used to find the effect of individual independent variables in explaining the related variables is the statistical test $t$. (Ghozali, 2012). This can be seen from:

1. If $t$ count $<t$-table, then the independent variables individually do not affect the dependent variable (hypothesis rejected)

2. If t count $>t$-table, then the independent variables individually affect the dependent variable (hypothesis accepted) 
In addition to the above method, the t-test can be shown from the significance value of table $t$ for each variable in the output of the regression results using SPSS. This is shown from if the significance is below $0.05(\mathrm{sig}<0.05)$ then the hypothesis is accepted and if the significance is above 0.05 (sig $>0.05$ ), the hypothesis is rejected.

Feasibility Model Test (Test F). The F test statistic is illustrated whether all independent variables have a relationship to the dependent variable. The $\mathrm{F}$ test aims to find the feasibility of the research model. The F test is performed by showing the sig F value at the output of the regression result by using SPSS with sig level $0.05(\mathrm{a}=5 \%)$. If the significance value is greater than Alpha $(\alpha)$, the hypothesis is rejected (regression coefficient rejected), which means the model in this study is not feasible.

Coefficient of Determination $\left(\mathbf{R}^{2}\right)$. The test used to find the ability of capital in explaining variations of the variables studied by showing the coefficient of determination $\left(\mathrm{R}^{2}\right)$. To show ability by showing the value of $\mathrm{R}^{2}$ this is between 0 and 1 . If the value $\left(\mathrm{R}^{2}\right)$ approaches 0 then it can be said that the ability of the independent variables to explain the related variables is also small. Whereas if the value $\left(R^{2}\right)$ is close to 1 it is stated that the ability of the variable explains the largely related variable or the independent variable giving all the information that is really needed by the related variable (Ghozali, 2012).

Hence it can be concluded that $\mathrm{R}^{2}=0$ means that there is no relationship between independent variables and related variables, while $\mathrm{R}^{2}=1$ signifies a perfect relationship.

\section{RESULT AND DISCUSSION}

Normality test. The normality test aims to find out whether the data is normally distributed. Normally distributed data produces good regression. To test the normality is done by Kolmogorov-Smirnov Test with a significance level of 5\%. This means that errors that can still be tolerated are 5\% with a confidence level of $95 \%$. Data is said to be not normally distributed if the significance is $<0.05$. Conversely, the data is said to be normally distributed if the significance is $>0.05$.

Table 1. Normality Test

\begin{tabular}{lc}
\hline & Unstandarized Residual \\
\hline Kolmogorov-Smirnov Z & 0.063 \\
\hline Asymp. Sig (2-tailed) & 0.200 \\
\hline Sourc: $($ Secondary data processed
\end{tabular}

Source: (Secondary data processed, 2018)

Based on the table above, the value of Asymp Sig (2-tailed) at the KolmogorovSmirnov test $<0.05$ which is equal to 0,000 . Thus, it can be concluded that the residual analysis results are normally distributed.

Heteroscedasticity Test. The aim of the regression model is to show whether the model has a variance of inequality from the residuals between observations of researchers using Heteroscedasticity tests. If the result of the observations is the same then it is called 
Homoscedasticity whereas if it is different it is called Heteroscedasticity. Detection of Heteroscedasticity can be seen using a graph and it is shown whether it forms a specific pattern on the scatter lite graph formed between SRESID and ZPRED. If the result in the graph forms a certain and regular pattern in the formation of patterns such as wavy patterns, widening and then narrowing, it can be stated that the regression model studied in the condition is not good or Heteroscedasticity occurs.

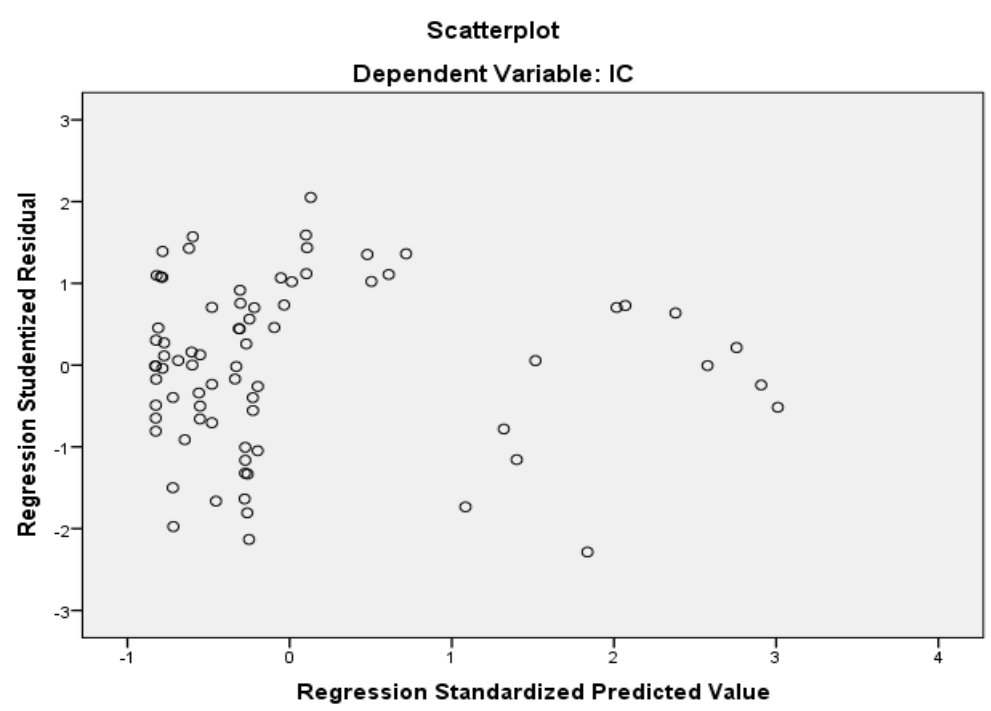

Figure 1. Heteroscedasticity test

Source: (Secondary data processed, 2018)

From the picture above shows that there is no clear pattern, and the points spread above and below the number 0 on the $\mathrm{Y}$-axis, it can be concluded that Heteroscedasticity does not occur.

Moderate Regression Analysis Test Result. After having a classic assumption test, the next step is at the table below:

Table 2. MRA Test Result

\begin{tabular}{lccc}
\hline Variable names & B & t Statistics & Significant \\
\hline Constant & 0.004 & 23.353 & 0.000 \\
\hline UP & $2.750 \mathrm{E}-17$ & 3.790 & 0.000 \\
\hline KA & -.030 & -1.104 & 0.273 \\
\hline Moderation & $-2.430 \mathrm{E}-15$ & -2.984 & 0.0004 \\
\hline
\end{tabular}

Source: (Secondary data processed, 2018)

Based on these result the regression equation is obtained as follows.

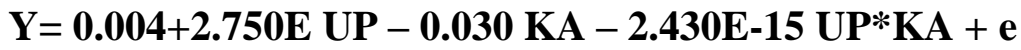


F-test. The F test is a test of the feasibility of the model in linear regression analysis. The F test is used to test the feasibility of the regression model used in testing the research hypothesis.

Table 3. F Test Result

\begin{tabular}{lccccc}
\hline \multicolumn{1}{c}{ Model } & Sum of Squares & $\boldsymbol{D} \boldsymbol{f}$ & Mean Square & $\boldsymbol{F}$ & Sig \\
\hline Regression & 0.000 & 3 & 0.000 & 10.157 & 0.000 \\
\hline Residual & 0.000 & 72 & 0.000 & & \\
\hline Total & 0.000 & 75 & & & \\
\hline
\end{tabular}

Source: (Secondary data processed, 2018)

Based on the table above, the significant level of the $F$ value is 0,000 . It can be concluded that the regression model used in this study is good.

Determination Coefficient Test $\left(\mathbf{R}^{2}\right)$. The coefficient of determination is used to determine the proportion or percentage of the total variance in the dependent variable explained by the independent variable. This study uses the adjusted.

Table 4. Determination Coefficient Test Result

\begin{tabular}{ccccc}
\hline Model & R & R Square & Adjusted R Square & Std. Error of the Estimate \\
\hline 1 & 0.545 & 0.297 & 0.268 & 0.00079 \\
\hline
\end{tabular}

Source: (Secondary data processed, 2018)

In the table above, the adjusted value obtained in this study amounted to 0.297 or $29.7 \%$. This means that $29.7 \%$ of the broad variance in intellectual disclosure of capital can be explained by foreign ownership variables and firm size. Therefore, the remaining $70.3 \%$ is influenced by other factors not examined in this study.

Individual Parameter Significance Test Result (t-Test). The t-test is used to test how far the independent variables individually explain the dependent variable. Based on the results of SPSS output, it shows that the foreign ownership variable has a significance of 0.004 where the significance is smaller than 0.05 . This shows that the foreign ownership variable is able to moderate the relationship of Company Size to Capital Intellectual Disclosure so that the hypothesis can be concluded accepted.

\section{DISCUSSION}

Based on observations for moderating foreign ownership variables, it is able to moderate the relationship between firm size and disclosure of capital intellectuals. This is indicated by the result of the significance of 0.004 smaller than 0.05 , so the hypothesis is accepted.

Based on signal theory is a theory that showed every organization tries to provide a positive signal to those who use information from these signals. The company tries to provide a positive signal to external parties in the form of useful information, one of which 
is the disclosure of capital intellectuals. Disclosure of intellectual capital is one of the voluntary disclosures issued by the company to describe the company's strategy and how companies use resources, especially human resources. Disclosure of intellectual capital can be used as a tool for resolving uncertainty regarding the condition of the company so that it can increase the value of a company so disclosure of intellectual capital is an important thing to be presented in financial statements (Ferchichi and Paturel, 2013).

Companies that have large companies tend to provide more information to external parties, especially shareholders. In addition, companies that are larger are indicated by the number of investors in the company and are shown also with high political costs because of non-compliance or the threat of policy usually have a higher quality of disclosure compared to companies with small scale (Ferreira et al., 2012). Thus, the size of a large company is expected to disclose intellectual capital higher. In this study, the moderating variable is foreign ownership. The bigger a company, it is more foreign ownership in the company. With a large number of foreign ownership in the company, the company provides more information to shareholders, the disclosure of intellectual capital will be higher. Furthermore, the result of this study stated that foreign ownership variables in this study are able to moderate the relationship between firm size and disclosure of intellectual capital. This is also shown from the research data, for example, the ASCII company which is a large-scale company is able to disclose capital intellectuals by $57 \%$ and have foreign ownership of $97 \%$. To state that foreign ownership is able to moderate the relationship between firm size and disclosure of capital intellectuals.

\section{CONCLUSION}

The conclusion in this study is that foreign ownership is able to moderate the relationship between Company Size and Intellectual Capital Disclosure. Companies that have large size companies tend to provide more information to external parties, especially shareholders. With a large company size, it is expected that the disclosure of intellectual capital will be higher. In this study, the moderating variable is foreign ownership. The bigger a company, it will be the more foreign ownership in the company. With so much foreign ownership in the company, the company will provide more information to shareholders so that the disclosure of intellectual capital is getting higher.

\section{REFERENCE}

Artinah, B. (2013). Faktor - Faktor Yang Mempengaruhi Pengungkapan Intellectual Capital Pada Lembaga Keuangan Yang Terdaftar di BEI. Jurnal Ilmu Sosial. Vol 5. No.2: 235 - 242.

Berzkalne, I., and Zelgalve, E. (2014). Intellectual Capital and Company Value. Contemporary Issues in Business, Management and Education, 110, 887-896.

Benedetta, Cuozzo, John Dumay, Matteo Palmaccio and Rosa Lombardi. (2017). Intellectual Capital Disclosure : A Structured Literature Review. Journal of Inttelectual Capital. Vol 18. Issue: $1 . \quad \mathrm{Pp} 9-28$. https ://doi.org.ezproxy.ugm.ac.id/10.1108/JIC-10-2016-0104. 
Brigham, Eugene F and Houston, Joel F. (2011). Dasar-Dasar Manajemen Keuangan. Edisi 11. Penerjemah Ali Akbar Yulianto. Jakarta: Salemba Empat.

Choirun, Nishak. (2017). Pengaruh Profitabilitas, Leverage, Ownership Retention dan Ukuran Perusahaan Terhadap Intellectual Capital Disclosure Pada Perusahaan Yang Melakukan Initial Public Offering. Artikel Ilmiah STIE Perbanas Surabaya.

Choi, H.M. Sul, W and Min, S.K. (2012). Foreign Board Member Ship And Firm Value In Korea. Management Decision. 50(2). PP207-233.

Devanela, Reditha dan Sekar, M. (2016). Faktor - Faktor Yang Mempengaruhi Pengungkapan Modal Intelektual. Media Riste Akuntansi, Auditing dan Informasi. Vol 16 No. 2 September 2016.

Eka, Nurmala Sari dan Yulida, Arisanti. (2018). Pengaruh Karateristik Perusahaan Terhadap Tingkat Pengungkapan Intellectual Capital Di Dalam Laporan Tahunan (Studi Pada Perusahaan Food And Beverages Yang Terdaftar Di Bursa Efek Indonesia Tahun 2010 - 2014). Jurnal Akuntansi dan Keuangan Methodist. eISSN : 2599 - 1175. Volume 1, 2018. 108 - 122. ISSN : 2599 - 0136.

Fatwa, Nuriziah dan Deni, Darmawati. (2014). Analisis Pengaruh Corporate Governance, Kepemilikan Manajerial dan Kepemilikan Institutional Terhadap Intellectual Capital Disclosure. Finance and Banking Journal. Vol 16 No. 2 Desember 2014.

Ferchichi, J., and Paturel, R. (2013). The Effect of Intellectual Capital Disclosure on the Value Creation: An Empirical Study Using Tunisian Annual Reports. International Journal of Accounting and Financial Reporting, 3(1), 81-107.

Ferreira, A. L., Moreira, J. A., and Branco, M. C. (2012). Factors Influencing Intellectual Capital Disclosure by Portuguese Companies. International Journal of Accounting and Financial Reporting, 2(2), 278-298.

Ghozali, Imam. (2012). Aplikasi Analisis Multivariate deangan Program IBM SPSS 20. Edisi Keenam. Semarang: Badan Penerbit Univesitas Diponegoro.

Heni, Oktavianti dan Wahidahwati (2014). Faktor - Faktor Yang Mempengaruhi Pengungkapan Intellectual Capital. Jurnal Ilmu dan Riset Akuntansi. Volume 3 No. 5.

Indra, Fery Irawan dan Tarmizi, Achmad. (2014). Analisis Pengaruh Ukuran Perusahaan Terhadap Kinerja Intellectual Capital Dengan Struktur Kepemilikan Sebagai Variabel Moderating. Diponegoro Journal Of Accounting. Vol 3. No.2. Tahun 2014: 1 - 11. ISSN (online) : 2337 - 3806 .

Jensen and Meckling. (1976). The Theory Of The Firm: Managerial Behavior, Agency Cost, And Ownership Structure. Journal Of Financial And Economic. 3:305-360.

Marisanti, Endang Kiswara. (2012). Analisis Hubungan Profitabilitas Terhadap Pengungkapan Intelektual Capital. Journal Of Accounting. Vol 1 No. 2 Hal $1-11$.

Mishari M. Alfraih. (2018). The Role Of Corporate Governance In Intellectual Capital Disclosure. International Journal Of Ethics And System. Vol 34. Issue: 1. pp 101121.

Purnomosidhi, B. (2016). Praktik Pengungkapan Modal Intelektual Pada Perusahaan Publik di BEJ. Jurnal Riset Akuntansi Indonesia. Vol. 9 No.1. Hal 1-20.

Pratingya, Utama dan Muhammad, Khafid. (2015). Faktor-Faktor Yang Mempengaruhi Luas Pengungkapan Modal Intelektual Pada Perusahaan Perbankan Di BEI Tahun 2011 - 2013. JABPI Vol 23, No 1 Januari 2015. ISSN : 1411.6871. 
Sri, Budhi Rezki. (2018). Determinan Faktor Pengungkapan Modal Intelektual Dan Tingkat Pengungkapan Per Industrinya Pada Seluruh Perusahaan Yang Terdafatar Di Bursa Efek Indonesia. Kompartemen : Jurnal Ilmiah Akuntansi. Maret 2018. XVI (1). $95-108$.

Soraya, Famadigma. (2015). Faktor - Faktor Yang Mempengaruhi Pengungkapan Intellectual Capital Pada Perusahaan Properti dan Real Estate. Jurnal Bisnis dan Manajemen Vol. 5 No. 2.

Republik Indonesia. Undang-Undang No. 25 Tahun 2007 tentang Penanaman Modal. Pasal 1 angka 6.

Wijoyo, Gendro. (2011). Merancang Penelitian Bisnis Dengan Alat Analisis SPSS 17.0 dan Smart PLS 2.0. UPP STIM YKPN. 